\title{
REVIEW: GERMINAL CELL APOPTOSIS BY HERBAL MEDICINE
}

\author{
PUTRI CAHAYA SITUMORANG, SYAFRUDDIN ILYAS*
}

Department of Biology, Faculty of Mathematics and Natural Sciences, Universitas Sumatera Utara, Medan 20155, Indonesia. Email: syafruddin6@usu.ac.id

Received: 02 April 2017, Revised and Accepted: 22 May 2018

\begin{abstract}
Apoptosis is a mechanism of cell death with a main role in cell recycling, which occurs in several organs: Testical, placenta, prostate, breast, ovarian, and cancer cells. Apoptotic signal pathway may be used to repair reproductive health disorders. Signal pathway of germ cell usually begins with extrinsic apoptotic pathway involving Fas/FasL molecule and mitochondrial pathway with Bcl-2 protein component. Apoptotic process in germ cell can also be triggered by exposing certain plant secondary metabolite to certain cells. Many plants have been reported successfully triggering apoptotic properties, i.e. (1) Areca catechu, (2) Carica papaya, (3) Camellia sinensis, (4) Curcuma domestica, (5) Costus speciosus, (6) Gossypium hirsutum, (7) Hibiscus spp., (8) Luffa aegyptiaca, (9) Momordica charantia, (10) Nicotiana tabacum, (11) Olea europaea, (12) Ocimum basilicum, and (13) Zingiber officinale. The metabolites may induce apoptosis through upregulating Fas/Fas-L and p53 expression, Bax/Bcl-2, along with caspase-3 activation. The mentioned plants then will induce apoptosis in germ cell and may become promising candidates to treat cancer as evidenced from extensive laboratory studies.
\end{abstract}

Keywords: Herbal, Apoptosis, Germ cell.

(C) 2018 The Authors. Published by Innovare Academic Sciences Pvt Ltd. This is an open access article under the CC BY license (http://creativecommons. org/licenses/by/4. 0/) DOI: http://dx.doi.org/10.22159/ajpcr.2018.v11i9.26400

\section{INTRODUCTION}

Apoptosis is a cellular key mechanism which explains the fate of cells and provides further insight into the mechanism of protection against reproductive toxicity [1]. Apoptosis is also called a programmed cell death with a major role in eliminating germ cells in all stages of oogenesis and even after ovulation [153,154]. More than 99\% of germ cells are eliminated in the ovaries through apoptosis through follicular atresia, while $<1 \%$ peaks into oogonia $[153,155]$. Oogonia in the meiotic stage produce primary oocytes $[154,157]$. Oocytes in the diplotene stage are encircled by layers of granulosa cells in the follicle $[158,159]$

Cigarette smoke (CS) has a strong link with carcinogens and change in metastesis-related gen expression in human ovarian by regulating celll cycle, effect on spermatogenesis in rat, infertily in men, hisologic reactions due to hypoxemia, damage to this limited pool of gametes in fertility in women [2-4]. Apoptosis of germ cells has been shown to play an important role in controlling sperm output in many species, and massive germ cell death occurs under physiological conditions during the first stages of spermatogenesis so called the constitutive apoptosis $[148,149]$. In the adult testes, germ cells strictly depend on the physical and biochemical support of Sertoli cells (SCs) and the somatic cells within the seminiferous tubules, which nourish and sustain the developing germ cells [143]. However, SCs have a limited capacity regarding the number of germ cells they can support, and it has been accepted that they play a crucial role in determining germ cell [144].

The association of death receptors and the extrinsic pathway of apoptosis with male infertility have been suggested by several studies, which showed an upregulated expression of FasL, resulting in maturation arrest and SC-only syndrome, characterized by the absence of germ cells in the seminiferous epithelium [150-152]. Alteration of sperm DNA has been found in pre-implanted embryos and lead offspring toward greater risk of malformation, cancer, and genetic diseases that may cause apoptosis and interference in the seminiferous tubules $[5,6]$.

Plumbum pollution can also significantly decrease sperm count, without any significant increase in the ratio of testes/100 g rat weight [7]. Heat stress may also cause DNA damage to germ cells and increase cell death (TUNEL assay), subfertility in stem cell death associated with increasing effector caspase expression (excision by caspase-3), and downregulation of protein called inhibitors caspaseactivated DNase [8]. P63 can also mediate the apoptosis of male germ cells and regulate three stages of spermatogenesis transcriptionally and could provide novel targets for the diagnosis and treatment of male infertility [9]. The novel apoptosis regulators such as aven, survivin, and regucalcin have also showed an altered expression in human testes with defective spermatogenesis [145-147]. Humanin prevented stress-induced apoptosis in many cells/tissues, with ameliorated chemotherapy, cyclophosphamide, and doxorubicin (DOX)-induced germ cell apoptosis in both ex vivo and in vivo tests using cultures of seminiferous tubule [10]

Mechanism and signal pathway can be utilized to improve reproductive health problems because signal pathway in germ cell usually uses an extrinsic apoptotic pathway involving Fas/FasL molecules and intrinsic or mitochondrial pathways [11]. In placental cells, chlorpyrifos (organophosphorus insecticides) induced apoptosis in placental cells through independent pathways of Fas/tumor necrosis factor signaling, caspase activation, or cholinesterase inhibition due to activation of p38 mitogen-activated protein kinase (MAPK) which was an integral part of cell protection against injury exposed to chlorpyrifos [12]. The placental tissue contains paternal antigens, and under normal condition, the semi-allogeneic fetus and placenta are not invaded by the maternal immune system because tolerance to fetal antigen occurs in the presence of large numbers of maternal leukocytes [13]. The process of apoptosis in germ cells can also be triggered by plants that contain unique secondary metabolites.

\section{ARECA CATECHU}

A. catechu consumed by the Asian community has four major alkaloids called arecoline, arecaidine, guvacoline, and guvacine [14]. Arecoline can pass through the basal membrane of seminiferous tubules and interacted with seminiferous tubular components, therefore altering gonadal function and sperm formation, and cause apoptosis in testicular tissue [15]. The plant is considered as a popular carcinogen because it contains apoptotic-inducing agents and may be used later as 
a new strategy to improve cancer therapy [16]. The effect of exposure to $A$. catechu seed water fraction has been reported to decrease sperm motility [15]. Induction of apoptosis in combination with DOX induced expression of Bax and caspase-3 proteins that mediate apoptosis based on immunocytochemistry study [17]. It also induced cytotoxicity and its genotoxicity under normal condition and may lead to the formation of larger tumors and oral squamous cell carcinoma [18]. Combination with alcohol indicated antifertility activity in the apoptotic area as shown from histological study [14]. The extract with doses above $40 \mathrm{~g} / \mathrm{mL}$ induced mutations in hypoxanthine so as to increase oxidative stress and genetic damage to human keratinocytes [19].

\section{CARICA PAPAYA}

C. papaya contains saponins, cardiac glycosides, anthraquinones, reducing sugars, flavonoids, alkaloids, and tannins with biological properties as antidiabetes, anti-inflammatory, anticancer, and other diseases [20]. Antioxidant and anticancer potential activities of the hexane fraction from the male flower of $C$. papaya have long been known as an important source of nutraceutical and pharmaceutical compounds [21]. Aqueous extract from C. papaya leaves reduced the incidence of sperm deformity by $12.37 \%$ and $6.53 \%$. Thus, another study reported a significant increase in the formation of luminous polychromatic erythrocytes with micronuclei (MNPCE) in bone marrow cells and sperm abnormalities [22]. A study with methanol subfraction from $C$. papaya seeds reduced the volume of the nucleus and cytoplasm, leading to damage of acrosome and mitochondria along with occurrence of apoptosis testis [23]. Another study reported combination of diet with Citrullus lanatus improved the potential of infertility in rats fed with C. papaya seed extract [24]. Antiproliferative effect of methylthiazolydiphenyltetrazolium bromide (MTT) and lipophilic extract of C. papaya ripening at different stages and times was exposed to breast carcinoma cell lines and did not inhibit cell proliferation of MCF-12F and MDA-MB-231, while showing a significant effect to MCF-7 cells within $72 \mathrm{~h}$ [25]. Percentage of MCF-7 cells exhibiting apoptosis in breast cancer exposed to C. papaya extract was lower than DOX, although in other case, the percentage was higher than quercetin result and thus may be considered as anticancer through anti-proliferative and apoptotic induction mechanisms [25]. Other study also reported the use of extract from unripe fruit of $C$. papaya $\mathrm{L}$. exhibiting an antineoplastic activity against Dalton's ascitic lymphoma cells in Swiss albino mice [26].

\section{CAMELLIA SINENSIS}

C. sinensis contains a major component of flavonoid and its derivatives, i.e., flavan-3-ols or catechin with medicinal properties along with its enzyme flavanone 3-hydroxylase which catalyzes stereospecific (2S)naringenin hydroxylation to form (2R, 3R)-dihydrokaempferol [27]. This plant has a strong inhibitory effect against free radicals and may exhibit potent anticancer activity [28]. C. sinensis extract is useful against tissue damage and hepatic dysfunction through antioxidants and anti-apoptosis in defense mechanisms [29,30]. Epigallocatechin gallate (EGCG) in this herb significantly reduced renal dysfunction, histological changes, and increasing expression of tumor necrosis factor- $\alpha$, IL-1 $\beta$, IL-6, Bax, and caspase [31]. Combination of green tea and vitamin $E$ in diabetic rats increased the number of apoptotic cells in testicular tissue [32]. Green tea extract has a protective effect on the testis by inhibiting oxidation of cadmium chloride $\left(\mathrm{CdCl}_{2}\right)$, resulting in cell damage and apoptosis [33,34].

Green tea extract also showed some protective effects to testis based on rats' study with malathion-induced testicular oxidative [35]. The plant also affected germ cells in the placenta significantly, due to the recovery of cellular homeostasis, through effective antioxidant capacity and prevention of cell damage during stressful conditions [36]. Selenium-containing polysaccharides in tea (Se-GTPs) triggered apoptosis pathways of mitochondrial with increased $\mathrm{Bax} / \mathrm{Bcl}-2$ ratio, caspase-3, and caspase-9 in MCF-7 cells [37]. Preventive mechanisms are commonly found with catechins activity of green tea extract, used in dietary and chemoprevention of carcinogenesis [38]. The combination of three natural products such as arctigenin which is a new antiinflammatory lignan in Arctium lappa seed, green tea polyphenols, EGCG, and curcumin (Cur) increased the chemopreventive potential of tLNCaP compounds in prosthetic and MCF-7 in breast cancer [39]. Purple tea extract also caused PARP cleavage, caspase- 3 activation, and increasing Bax/Bcl-2 ratio in colorectal carcinoma cell proliferation [40].

\section{CURCUMA DOMESTICA}

C. domestica contains curcumin (diferuloylmethane), demethoxycurcumin, and bisdemethoxycurcumin as well as volatile oils (tumerone, atlantone, and zingiberone), sugars, proteins, and resins [41]. In India, Curcuma undergoes genetic variation in its population due to a wide range of ecological conditions and distribution [167]. The secondary metabolite, namely, curcumin hindered the synthesis of aflatoxin by Aspergillus flavus [42]. Demethoxycurcumin and bisdemethoxycurcumin in curcuminoid were found to be varied in two samples regarding the pharmacological activities [43]. Curcumin decreased MDA levels in pre-eclampsia by lowering blood pressure and protein levels in the urine [44]. Curcumin also decreased depolarization of mitochondrial membranes and expression of apoptotic proteins [45]. In male germ cells, $C$. domestica showed protective effect despite its also damages to testes [46]. Treatment of $C$. domestica reduced apoptosis in the testes and decreased expression of Fas, Bax, and cleaved-caspase- 3 and also increased expression of Bcl-xl [47]. It also improved testicular histological qualities and significantly reduced apoptotic levels by inhibiting oxidative stress and modulating cell death pathway-mediated Bax/Bcl-2 [48,49]. It inhibited proliferation of NTera- 2 cells through signal pathways and caused apoptosis by reducing FasL expression and Bcl-2-to-Bax ratio and activating caspases 9, 8, and 3 [48,50]. However, When caspase 3 active in germ cells like spermatogonia, spermatocytes and spermatids, encourage of decreasing spermatozoa concentration [51].

Curcumin inhibited cell growth by inducing apoptosis on cancer cells but not on normal cells, and PGV-1 cell showed the strongest apoptosis induction effect on cancer cell lines [52]. Combination of $C$. domestica and Apo2L/TRAIL ligands increased the induction of apoptotic cell death in ovarian cancer by activating extrinsic and intrinsic pathways of apoptosis [53]. C. domestica also induced G2/M phase cells in CR cells by increasing phosphorylation of p53 and apoptosis through caspase-3 activation and PARP degradation [54]. Combination of arsenic and chlorpyrifos triggered apoptosis, but $C$. domestica simultaneously inhibited apoptosis because of its antioxidant properties [55]. A study showed that $C$. domestica inhibited the proliferation of cancer cells through molecular mechanisms [56]. The molecular mechanism of C. domestica for breast cancer by inhibiting proliferation of MDAMB-231 and BT-483 cells was through p21 expression, mediated by NF- $\kappa \mathrm{B}$, cyclin $\mathrm{D}$, and MMP-1 regulation $[57,58]$. C. domestica also altered cellular response through a p53-dependent pathway, in which Bax acted as p53 effector [59]. The plant significantly reduced tumor size and its proliferation with a combination of $C$. domesticapaclitaxel for the treatment of breast cancer [60]. Other mechanism reported was the inhibition to migration and invasion of N18 cells that acted as preventive agent in metastatic cancer [45]. C. domestica also significantly inhibited apoptosis of ESC-B5 cells in mice and blastocysts induced by methylglyoxal [61]. The chromatography technique, namely, reverse-phase high-performance liquid chromatography was very useful in quantifying and controlling the quality of extracted curcumin [166].

\section{COSTUS SPECIOSUS}

C. speciosus contains ascorbic acid, beta-carotene, alpha-tocopherol, glutathione, phenols, flavonoids, alkaloids and terpenoids, and flavonoids [62]. C. speciosus possessed potential antimicrobial activity against Escherichia coli, Staphylococcus aureus, Klebsiella pneumoniae, and Pseudomonas aeruginosa which commonly used and served as therapy in traditional medicine [63]. This plant exhibits biochemical effect on serum glucose, serum cholesterol (Chol), carcinoembryonic 
antigen, and carbohydrate antigens [64]. Diosgenin isolated from $C$. speciosus inhibits cell viability, generating induction in cell proliferation, and significantly increased caspase-3 in MCF-7 cells [65]. Diosgenin with taurine decreased the number of forming spermatogonia, spermatocytes, and spermatid cells [66]. Combination of DOX and hesperidin also led to increasing MC-7 cell apoptosis and was developed as chemotherapy agent to breast cancer [67]. Other components, namely, costunolide in this plant induced apoptosis of breast cancer cells [68]. The costunolide acted with SOD, catalase, and GPx as potential antioxidant agents in human breast cancer cells through apoptosis mechanism [69]. It also synergized with the use of Rhaphidohora pinnata as inhibitor of cell proliferation and apoptosis to MCF-7 cells [70].

\section{GOSSYPIUM HIRSUTUM}

G. hirsutum contains phenolic compounds and hydrolytic enzymes including $\beta$-glucosidase, carboxylesterase, and glutathione-Stransferase [71]. Mice treated with gossypol acetic acid exhibit a SC toxicity and seminiferous tubular degeneration in sperm with increasing activity of $17 \beta$-hydroxysteroid dehydrogenase and 17-ketosteroids [72]. Combination of gossypol with methyltestosterone and ethinylestradiol was reported to act as contraceptive agents by involving the system of Fas, Bax, caspase, and apoptotic in intrinsic and extrinsic pathways [73]. G. hirsutum induced a decrease in pro-survival regulation of Bcl-xl and Mcl-1 proteins that increased the sensitivity of urinary cancer cells toward carboplatin and gemcitabine [74]. Carboplatin from $G$. hirsutum at a concentration of $380 \mathrm{mg} / \mathrm{mL}$ inhibited ovarian cancerous and tumorous cells [75]. G. hirsutum also disrupted estrous cycle by reducing number of follicles in female reproduction [76]. It affects granulosa cell activity in vitro and might recover fertility in pigs [77]. Combination with zoledronic acid produced a synergistic cytotoxicity and direct inhibition to cell proliferation, although it also possessed some side effects to certain molecules in angiogenesis [78].

\section{HIBISCUS SABDARIFFA}

Hibiscus spp. contains triterpene, fitosteroid, phenolic, and flavonoids that are capable of preventing the proliferation of malignant cells in the development of new anticancer drugs $[79,80]$. Purified H. sabdariffa with ellagic acid compounds exhibited apoptotic properties through intrinsic and extrinsic apoptotic pathways that inhibited the growth of LNCaP cells in prostate cancer [81]. However, a study reported treatment using Hibiscus which caused a reversible suppression of spermatogenesis, cholesterol levels, glucose levels and changes in the seminiferous tubules, and germinal epithelial density [82]. Combination of $H$. sabdariffa and Zingiber officinale increased antioxidant level and enzyme activity in the testes as to restore the motility of rat spermatozoa treated with cisplatin [1]. Aqueous $H$. sabdariffa extract inhibited the growth of MCF-7 cells [57]. However, anthocyanins isolated from H. sabdariffa failed to stimulate proteins associated with apoptosis Bcl-2, Bax, and AMP-activated kinase [83]. H. sabdariffa also inhibited the proliferation of serum stimulatory smooth muscle cells and triggered apoptosis through the activating protein kinase P38 (MAPK) pathway[82]

\section{LUFFA AEGYPTIACA}

L. aegyptiaca contains alkaloids and saponins with known antimicrobial activities against E. coli, S. aureus, Salmonella typhi, and Bacillus subtilis [165]. The extract from Luffa aegyptiaca also possessed potential antioxidant and anthelmintic activity [84]. Caspase-3 may be activated by caspase-8 so as to trigger germ cell apoptosis. Combination of testosterone undecanoate (TU) with L. aegyptiaca (Blustru) extract increased the activity of caspase- 3 molecules, triggering the occurrence of germinal cell (apoptotic) fragmentation through decreasing testosterone and thereby decreasing the quality and quantity of spermatozoa. Combination of hormones increased apoptosis in germ cells, causing azoospermia [164]. Other Luffa species, namely, L. cylindrical seed extract contains Luffin-a which is a single Type I protein inactivation (the most toxic in the Luffin family) possessed antitumor activity by inhibiting protein synthesis in rabbit reticulocyte while inducing apoptosis [85]. In addition to germ cell apoptosis, $L$. aegyptiaca (cylindrica) also possessed great potential to remove heavy metals in water, although still not standardized as a drinking water media filter [86].

\section{MOMORDICA CHARANTIA}

M. charantia contains two classes of saponins, namely, cucurbitane and oleanane types that can reduce cell viability and reduce lipid accumulation [87]. The presence of high total phenolic acid content in $50 \%$ ethanol extract of this plant may act as an anticancer agent [88]. The high dose of $M$. charantia extract caused infertility in the seminiferous tubules and testosterone levels that affected sperm motility and acrosome membranes [89]. M. charantia was also reported as pharmacological and phytochemical extract with antidiabetic activity [90]. Methane extract of M. charantia seed + depot medroxyprogesterone acetate (DMPA) can be used as a male contraceptive tool in the future, as it accelerated the decrease of progesterone production (precursor testosterone) and reduced the quantity and quality of sperm in rats [91]. DMPA reduced sperm viability due to its terpenoid effects that trigger pro-apoptotic proteins such as Bax, Bid, and p53 in which later increased the incidence of apoptosis [92]. This plant induced caspase- 3 cleavage, DFF-45, and PARP activation, which caused DNA fragmentation by triggering apoptosis through the path of caspases and mitochondrial pathways in cancer cells [93]. It also significantly decreased the formation of micronucleus, inhibited chromosomal aberrations, and increased the mitotic index [94]. Methane extract of M. charantia seed and DMPA affected stem cell activity in signal transduction as shown by histological image of mice cerebellum $[95,96]$. Administration of ethanol extract induced apoptosis in rat testes with increasing expression of Fas/Fas-L and $\mathrm{p} 53$, regulation of $\mathrm{Bax} / \mathrm{Bcl}-2$ ratio, cytochrome $\mathrm{c}$ translocation with caspase-3 activation, and glutathione depletion [97]. MCF-7 cells treated with $M$. charantia during G2-M phase increased expression of p53 and p21; pChk1/2 inhibited the expression of cyclin B1 and cyclin D1 by involving regulation of cell cycle, thus inhibiting the growth of breast cancer cells [98]. Combination of M. charantia and C. domestica prevented cell damage and provided significant protection against changes in malondialdehyde (MDA), conjugated diene, and defense antioxidants [99]. Tahitian noni dietary supplements can also improve testicular toxicity supplemented with high doses of M. charantia extract [100].

\section{NICOTIANA TABACUM}

N. tabacum contains alkaloids, fatty acids, nitrogen, fluorine, sulfur, and oxygen-containing compounds [101]. N. tabacum may pass its compounds through the placenta and then causing apoptosis, affecting sex hormone secretion, germ cell extension, and infertility in men [102]. Fetal membranes exposed to $N$. tabacum were experiencing apoptosis in a non-inflammatory pathway on pPROM that increased proteolysis resulting in membrane weakening and rupture [103]. Exposure of $N$. tabacum during pregnancy and lactation can lead to transient structural changes in the male fetal testes and epididymis and the number of germ cells and somatic embryos [104,105]. MicroRNA/miRNA exposed to cigarette smoke compared with controls was highly responsive to the exposure on placenta [106]. The fate of fetus may be critical, when germinal cells resolved proliferation, in which their germ cells were multiplied by $29 \%$, although bud cell apoptosis was unaffected in germ cells within ovaries, expressing AhR at the stage of proliferative development (meiotic stage) [107]. N. tabacum also acted by suppressing testosterone biosynthesis, reducing mRNA levels, Bcl-2 protein, regulating p53, caspase-3 mRNA, and protein levels that may affect spermatogenesis [108]. Aqueous extract of $N$. tabacum was considered as a potential endocrine disruptor that may affect the micro-anatomical form and testicular function [109]. However, $N$. tabacum showed a slight effect on body weight although this effect was significantly low [110]. 


\section{OLEA EUROPAEA}

O. europaea contains exogenous antioxidants with various benefits. Olives converted to Extra virgin olive oil (Evoo) possessed analgesic, anti-inflammatory, and anticancer properties [111]. EVOO was reported to able to control the induction of Hsp70 serum levels, thereby reducing growth of cell due to fetal complications in pre-eclampsia [160]. Induction of Hsp 70 may cause germ cell damage, cancerous cells, and apoptosis in mouse cochlea by cooperating with caspase-3 [112-114]. Provision of serelaxin improved the pathophysiology of placental ischemia in preeclampsia rats [115]. The ability of polyphenols in EVOO to inhibit HER2 activity significantly affected breast cancer cell proliferation, although no significant effect was observed on the metastasis of gene expression in HT115 cells through molecular mechanisms [116-118]. Depending on its structure, some polyphenols (e.g., flavonoids) modulated tyrosine HER2 receptor kinase in human breast epithelial cells based on in vitro transformation study [119]. Effects of oleuropein on breast cancer cell death was also reported from 0 . europaea and suggested the specific cytotoxicity in breast cancer cells, with a higher effect on MDAMB-231 cells [120]. Combination of EVOO and high supplementation of corn oil provided modulation effects on breast cancer through a combination of different signaling pathways [121]. In addition, EVOO also possessed neuroprotective activity that may counter the oxidative damage to the brain caused by 2,4-D [122].

\section{OCIMUM BASILICUM}

O. basilicum contains alkaloids, phytosterols, resin, flavonoids, tannins, diterpenes, and protein in the seed extract [124]. O. basilicum possessed anti-proliferative activity in testicular apoptosis because Cd increased Bax and decreased Bcl-2 in germ cells [123]. Ocimum was also known for its antioxidant activity while may also trigger testicular apoptosis occurred due to decrease in cell proliferation and Ki-67 expression [125]. In addition, the plant caused elevation of glucose levels in the testes and epididymis and served as a substrate for gluconeogenesis [127]. Methanol extract of $O$. basilicum possessed a considerable anti-proliferative activity against the MCF-7 cells [161]. The purified essential oil of the plant inhibited the proliferation $\left(\mathrm{IC}_{50}=170 \mu \mathrm{g} \cdot \mathrm{mL}^{-1}\right)$ of Michigan-7 cancer stem cells (MCF-7) that later induced apoptosis and acted as a pro-apoptotic inducer or acted as an anticancer agent [37]. And up-regulated the expression of apoptotic gene and as well increased the bax/bcl2 ratio [126]. The plant constituents also increased choline acetyltransferase (ChAT) expression and restored ChAT expression due to deterioration of human cerebral microvascular endothelial cells in nerve cells [128]. O. basilicum may also reduce electromagnetic exposure to testicular histologic apoptosis [162]. As from other study, there was a clear evidence of potential triggering effect of uterine apoptosis using electromagnetic fields' laboratory technique [129].

\section{Z. OFFICINALE}

Z. officinale contains several bioactive constituents with the highest total amount of phenolics and flavonoids in the rhizomes and stems [130]. Treatment with $Z$. officinale improved histological changes, reduced apoptosis in rat testes, and caused a decrease in the percentage of apoptotic cells in positive Bax cells [131]. The extract repaired cells induced by Sodium arsenite arsenite which caused oxidative stress that contributed to reproductive damage in male rats [132]. The reproductive system of mice exposed to formalin $10 \%$ significantly induced oxidative stress [133]. Oral administration improved weight, decreased antioxidant enzyme activity, and increased MDA and serum total homocysteine [134]. Z. officinale also improved testosterone and luteinizing hormone levels due to exposure of mancozeb-fungicide induction [135]. The plant may become a promising candidate for the treatment of breast carcinoma because it decreases the expression of pro-survival genes, such as NF- $\mathrm{KB}$, Bcl-X, Mcl-1, survivin, and cell cycle regulatory proteins including cyclin D1 and cyclin-dependent kinase-4 [163]. The extract may also improve the effects of $\mathrm{CdCl}_{2}$ as a toxin that induces changes in the uterus and ovaries [136]. Treatment of steam distilled extract of ginger mediated apoptosis by activating p53 and other agents in the treatment of endometrial cancer [137]. Ginger varieties with high $\mathrm{CO}_{2}$ concentrations can be used against two cancer cell lines in humans (MCF-7 and MDAMB-231), especially breast cell lines [138].Compounds like 6-gingerol in this plants, and combination with PI-3K inhibitors and cisplatin was considered safe and has potential in Cervical cell lines and anti-tumor activity in human cancer cells [139]. Combination of Z. officinale and Piper retrofractum induced myeloma and WiDr cells with apoptotic activity and increased expression of p53 [140]. ZER-HP $\beta C D$ complex isolated from $Z$. officinale acted as a promising anticancer agent through apoptotic mechanism [141]. The plant also possessed an ameliorative effect on kidney damage induced by metalaxyl [142].

\section{CONCLUSION}

Apoptosis caused by incorporation of plant extracts into several in vitro studies has shown promising result. The plants who successfully triggering apoptotic i.e (1) A. catechu, as apoptotic inducing agents and as a new strategy to improve cancer therapy; (2) C. papaya, as apoptotic inducing in testis and breast cancer; (3) C. sinensis, as apoptotic inducing in testicular tissue, affected germ cells in the placenta, and potent anticancer activity; (4) C. domestica, as apoptotic inducing in ovarian cancer; (5) C. speciosus, as apoptotic inducing in breast cancer cells and decreased the number of spermatogonia, spermatocytes, and spermatid cells. (6) G. hirsutum, as apoptotic inducing, contraceptive agents, and treatment of ovarian cancer; (7) Hibiscus spp., as apoptotic inducing spermatogenesis; (8) L. aegyptiaca, as apoptotic inducing in germinal cell, through decreasing testosterone; (9) M. charantia, as apoptotic inducing in rat testis, and inhibiting the growth of breast cancer cells; (10) N. tabacum, as apoptotic inducing, affecting sex hormone secretion, germ cell extension, infertility in men, and increase proteolysis in membrane weakening and rupture in fetal; (11) 0 . europaea, as apoptotic inducing on breast cancer and reducing growth of cell due to fetal in pre-eclampsia; (12) 0 . basilicum, as apoptotic inducing, pro-apoptotic inducer by electromagnetic exposure; (13) $Z$. officinale, as apoptotic inducing in endometrial cancer and promising anticancer through apoptotic.

\section{AKNOWLEDGEMENT}

We are grateful to Directorate of research and community service, Directorate general of research and development, Ministry of research, Technology, and Higher Educationfor providing to fund of the research (Competency based research grant 3rd years-DRPM Jakarta) to publish our journal.

\section{CONFLICTS OF INTEREST}

The authors have declared no conflicts of interest.

\section{AUTHORS' CONTRIBUTION}

Putri Cahaya Situmorang undertook the most part during preparation of manuscript and Syafruddin Ilyas acted as corresponding author with responsibility to review the content and English grammar.

\section{REFERENCES}

1. Amin A, Hamza AA, Kambal A, Daoud S. Herbal extracts counteract cisplatin-mediated cell death in rat testis. Asian J Androl 2008;10:291-7.

2. Jeon SY, Go RE, Heo JR, Kim CW, Hwang KA, Choi KC. Effects of cigarette smoke extracts on the progression and metastasis of human ovarian cancer cells via regulating epithelial-mesenchymal transition. Reprod Toxicol 2016;65:1-10.

3. Ahmadnia H, Ghanbari M, Moradi MR, Khaje-Dalouee M. Effect of cigarette smoke on spermatogenesis in rats. Urol J 2007;4:159-63.

4. Camlin NJ, McLaughlin EA, Holt JE. Through the smoke: Use of in vivo and in vitro cigarette smoking models to elucidate its effect on female fertility. Toxicol Appl Pharmacol 2014;281:266-75.

5. Esakky P, Hansen DA, Drury AM, Moley KH. Cigarette smoke condensate induces aryl hydrocarbon receptor-dependent changes in gene expression in spermatocytes. Reprod Toxicol 2012;34:665-76. 
6. Calogero A, Polosa R, Perdichizzi A, Guarino F, La Vignera S, Scarfia A, et al. Cigarette smoke extract immobilizes human spermatozoa and induces sperm apoptosis. Reprod Biomed Online 2009;19:564-71.

7. Ilyas S. Influence of chitosan from shrimp skin to quality and quantity of sperm of albino rats after administration of lead. Androl Open Access 2014;3:1-5.

8. Paul C, Teng S, Saunders PT. A single, mild, transient scrotal heat stress causes hypoxia and oxidative stress in mouse testes, which induces germ cell death. Biol Reprod 2009;80:913-9.

9. Wang H, Yuan Q, Niu M, Zhang W, Wen L, Fu H, et al. Transcriptional regulation of P63 on the apoptosis of male germ cells and three stages of spermatogenesis in mice. Cell Death Dis 2018;9:76.

10. Jia Y, Ohanyan A, Lue YH, Swerdloff RS, Liu PY, Cohen P, et al. The effects of humanin and its analogues on male germ cell apoptosis induced by chemotherapeutic drugs. Apoptosis 2015;20:551-61.

11. Tripathi R, Mishra DP, Shaha C. Male germ cell development: Turning on the apoptotic pathways. J Reprod Immunol 2009;83:31-5.

12. Saulsbury MD, Heyliger SO, Wang K, Round D. Characterization of chlorpyrifos-induced apoptosis in placental cells. Toxicology 2008:244:98-110.

13. Renaud SJ, Graham CH. The role of macrophages in utero-placental interactions during normal and pathological pregnancy. Immunol Invest 2008;37:535-64.

14. Srimany A, George C, Naik HR, Pinto DG, Chandrakumar N, Pradeep T, et al. Developmental patterning and segregation of alkaloids in areca nut (seed of areca catechu) revealed by magnetic resonance and mass spectrometry imaging. Phytochemistry 2016;125:35-42.

15. Akmal M, Siregar TN. Efek paparan dekok biji pinang (Areca catechu) terhadap motilitas spermatozoa tikus (Rattus norvegicus): Upaya menemukan kandidat. Ked Hewan 2008;2:137-42.

16. Yen CY. Areca nut contains both apoptosis- and autophagy-inducing ingredients and its possible effects on cancer cells. J Biomed Sci 2016;5:3-7.

17. Rahmi F, Meiyanto E, Susidarti RA. Combination of doxorubicin and areca ethanolic extract induces apoptosis by increasing caspase-3 level on breast cancer (T47D) cells. Indones J Cancer Chemoprevention 2012;3:339-44.

18. Li WC, Lee PL, Chou IC, Chang WJ, Lin SC, Chang KW, et al. Molecular and cellular cues of diet-associated oral carcinogenesis with an emphasis on areca-nut-induced oral cancer development. J Oral Pathol Med 2015;44:167-77.

19. Lai KC, Lee TC. Genetic damage in cultured human keratinocytes stressed by long-term exposure to areca nut extracts. Mutat Res 2006;599:66-75.

20. Patil T, Patil S, Patil A, Patil S. Carica papaya leaf extracts - An ethnomedicinal boon. Int J Pharmacogn Phytochem Res 2014;6:2.

21. Sianipar MP, Suwarso ED, Rosidah R. Antioxidant and anticancer activities of hexane fraction from Carica papaya L. male flower. Asian J Pharm Clin Res 2018;11:10-2.

22. Journal W, Sciences P, Badr TM, Kamel AM. Ameliorative effect of aqueous extract of Carica papaya leave against high body temperature. World J Pharm Pharm sci 2015;4:104-23.

23. Manivannan B, Mittal R, Goyal S, Ansari AS, Lohiya NK. Sperm characteristics and ultrastructure of testes of rats after long-term treatment with the methanol subfraction of Carica papaya seeds. Asian J Androl 2009;11:583-99.

24. Amedu N, Idoko U. Dietary consumption of Citrullus lanatus can ameliorate infertility potential of Carica papaya seeds extract in male rats. Br Biotechnol J 2016;11:1-9.

25. Sancho LG, Yahia EM, García-solís P, González-aguilar GA. Inhibition of proliferation of breast cancer cells MCF7 and MDA-MB-231 by lipophilic extracts of papaya (Carica papaya L. var. maradol) fruit. Food Nutr Sci 2014;5:2097-103.

26. Praveena P, Jethinlalkhosh JP, Doss VA. Evaluation of uterotonic activity of hydro-ethanolic extract of unripe fruit of Carica papaya Linn. using wistar albino rats. Indian J Pharm Educ Res 2017;51:S615-22.

27. Singh K, Rani A, Kumar S, Sood P, Mahajan M, Yadav SK, et al. An early gene of the flavonoid pathway, flavanone 3-hydroxylase, exhibits a positive relationship with the concentration of catechins in tea (Camellia sinensis). Tree Physiol 2008;28:1349-56.

28. Lin JN, Lin HY, Yang NS, Li YH, Lee MR, Chuang CH, et al. Chemical constituents and anticancer activity of yellow camellias against MDA-MB-231 human breast cancer cells. J Agric Food Chem 2013:61:9638-44.

29. Gawish AM, Ramadan S, Hassan AM, Issa AM. Morphometrical, histopathological, and cytogenetical ameliorating effects of green tea extract on nicotine toxicity of the testis of rats. J Cytol Histol
2010;1:1-7.

30. Hung GD, Li PC, Lee HS, Chang HM, Chien CT, Lee KL, et al. Green tea extract supplementation ameliorates CCl4-induced hepatic oxidative stress, fibrosis, and acute-phase protein expression in rat. J Formos Med Assoc 2012;111:550-9.

31. Lv J, Feng M, Zhang L, Wan X, Zeng YC, Liang PF, et al. Protective effect of epigallocatechin gallate, a major constituent of green tea, against renal ischemia-reperfusion injury in rats. Int Urol Nephrol 2015;47:1429-35

32. Kaplanoglu GT, Bahcelioglu M, Gozil R, Helvacioglu F, Buru E, Tekindal MA, et al. Effects of green tea and vitamin $\mathrm{E}$ in the testicular tissue of streptozotocin-induced diabetic rats. Saudi Med J 2013;34:734-43.

33. Abdelrazek HM, Helmy SA, Elsayed DH, Ebaid HM, Mohamed RM. Ameliorating effects of green tea extract on cadmium induced reproductive injury in male wistar rats with respect to androgen receptors and caspase- 3. Reprod Biol 2016;16:300-8.

34. Hijazi MM, Khatoon N, Azmi MA, Rajput MT, Zaidi SI, Azmi MA, et al. Report: Effects of Camellia sinensis L. (green tea) extract on the body and testicular weight changes in adult wistar rate. Pak J Pharm Sci 2015;28:249-53.

35. Nahid Z, Tavakol HS, Abolfazl GK, Leila M, Negar M, Hamed F, et al. Protective role of green tea on malathion-induced testicular oxidative damage in rats. Asian Pacific J Reprod 2016;5:42-5.

36. Padmini E, Lavanya D, Tharani J, Lavanya S. Tea and mint extracts modulate the HSP70 expression in preeclamptic placental explant. J Appl Pharm Sci 2012;2:128-33.

37. He N, Shi X, Zhao Y, Tian L, Wang D, Yang X, et al. Inhibitory effects and molecular mechanisms of selenium-containing tea polysaccharides on human breast cancer MCF-7 cells. J Agric Food Chem 2013;61:579-88.

38. Rathore K, Wang HC. Green tea catechin extract in intervention of chronic breast cell carcinogenesis induced by environmental carcinogens. Mol Carcinog 2012;51:280-9.

39. Wang P, Wang B, Chung S, Wu Y, Henning SM, Vadgama JV, et al. Increased chemopreventive effect by combining arctigenin, green tea polyphenol and curcumin in prostate and breast cancer cells. RSC Adv 2014:4:35242-50.

40. Hsu CP, Shih YT, Lin BR, Chiu CF, Lin CC. Inhibitory effect and mechanisms of an anthocyanins- and anthocyanidins-rich extract from purple-shoot tea on colorectal carcinoma cell proliferation. J Agric Food Chem 2012;60:3686-92.

41. Panigrahi S, Mahapatra S. Evaluation of antibacterial activity of Pongamia pinnata L., Curcuma longa L. and Mentha arvenis L. against Staphylococcus aureus. Int J ChemTech Res 2016;9:205-12

42. Ferreira FD, Kemmelmeier C, Arrotéia CC, da Costa CL, Mallmann CA, Janeiro V, et al. Inhibitory effect of the essential oil of Curcuma longa L. And curcumin on aflatoxin production by aspergillus flavus link. Food Chem 2013;136:789-93.

43. Tejavathi DH, Sujatha BS, Kannan R. Estimation of curcuminoids in Curcuma karnatakensis (White turmeric) - An endemic taxon. Asian J Pharm Clin Res 2017;10:10.

44. Yeni CM, Fauziah PN, Maskoen AM, Ruslami R, Mose J. Effect of curcumin in decreasing MDA level in preeclampsia-induced human umbilical vein endothelial cell. Int J Pharm Tech Res 2017;10:69-73.

45. Lim W, Jeong M, Bazer FW, Song G. Curcumin suppresses proliferation and migration and induces apoptosis on human placental choriocarcinoma cells via ERK1/2 and SAPK/JNK MAPK signaling pathways. Biol Reprod 2016;95:83

46. Głombik K, Basta-Kaim A, Sikora-Polaczek M, Kubera M, Starowicz G, Styrna J, et al. Curcumin influences semen quality parameters and reverses the di(2-ethylhexyl)phthalate (DEHP)-induced testicular damage in mice. Pharmacol Rep 2014;66:782-7.

47. Mu Y, Yan WJ, Yin TL, Yang J. Curcumin ameliorates high-fat diet-induced spermatogenesis dysfunction. Mol Med Rep 2016;14:3588-94.

48. Zhao L, Gu Q, Xiang L, Dong X, Li H, Ni J, et al. Curcumin inhibits apoptosis by modulating bax/Bcl-2 expression and alleviates oxidative stress in testes of streptozotocin-induced diabetic rats. Ther Clin Risk Manag 2017:13:1099-105.

49. Kanter M, Aktas C, Erboga M. Curcumin attenuates testicular damage, apoptotic germ cell death, and oxidative stress in streptozotocininduced diabetic rats. Mol Nutr Food Res 2013;57:1578-85.

50. Zhou C, Zhao XM, Li XF, Wang C, Zhang XT, Liu XZ, et al. Curcumin inhibits AP- $2 \gamma$-induced apoptosis in the human malignant testicular germ cells in vitro. Acta Pharmacol Sin 2013;34:1192-200.

51. Ilyas S. Analysis of protein fas expression and caspase 3 activated at the supression phase to sperm quantity by androgen/progestin combination. 
Sumatera J Biol Sumatera 2007;2:2.

52. Da'i M. I, Suhendi A, Meiyanto ED, Jenie UA, Kawaichi M. Apoptosis induction effect of curcumin and its analogs pentagamavunon- 0 and pentagamavunon-1 on cancer cell lines. Asian J Pharm Clin Res 2017;10:5-8.

53. Wahl H, Tan L, Griffith K, Choi M, Liu JR. Curcumin enhances apo2L/ TRAIL-induced apoptosis in chemoresistant ovarian cancer cells. Gynecol Oncol 2007;105:104-12.

54. Weir NM, Selvendiran K, Kutala VK, Tong L, Vishwanath S, Rajaram M, et al. Curcumin induces G2/M arrest and apoptosis in cisplatin-resistant human ovarian cancer cells by modulating akt and p38 MAPK. Cancer Biol Ther 2007;6:178-84.

55. Prakash A, Khan S, Kumar D, Telang AG, Malik JK. Research article concurrent administration of curcumin mitigates arsenic-and chlorpyrifos-induced apoptosis in rat thymocytes. Adv Anim Vet Sci 2014;2:407-13.

56. Liu XE. Curcumin induces apoptosis of triple-negative breast cancer cells by inhibition of EGFR expression. Mol Med Rep 2012;1:1267-70.

57. Liu D, Chen Z. The effect of curcumin on breast cancer cells. J Breast Cancer 2013;16:133-7.

58. Liu Q, Loo WT, Sze SC, Tong Y. Curcumin inhibits cell proliferation of MDA-MB-231 and BT-483 breast cancer cells mediated by down-regulation of NFkappaB, cyclinD and MMP-1 transcription. Phytomedicine 2009;16:916-22.

59. Choudhuri T, Pal S, Agwarwal ML, Das T, Sa G. Curcumin induces apoptosis in human breast cancer cells through p53-dependent bax induction. FEBS Lett 2002;512:334-40.

60. Kang HJ, Lee SH, Price JE, Kim LS. Curcumin suppresses the paclitaxel-induced nuclear factor-kappaB in breast cancer cells and potentiates the growth inhibitory effect of paclitaxel in a breast cancer nude mice model. Breast J 2009;15:223-9.

61. Hsuuw YD, Chang CK, Chan WH, Yu JS. Curcumin prevents methylglyoxal-induced oxidative stress and apoptosis in mouse embryonic stem cells and blastocysts. J Cell Physiol 2005;205:379-86.

62. Chandra K, Salman AS, Mohd A, Sweety R, Ali NK. Protection against FCA induced oxidative stress induced DNA damage as a model of arthritis and in vitro anti-arthritic potential of Costus speciosus rhizome extract. Int J Pharmacogn Phytochem Res 2015;7:383-9.

63. Saraf A. Phytochemical and antimicrobial studies of medicinal plant Costus speciosus (Koen.). E J Chem 2010;7:S405-13.

64. Abdel-Maksoud H, Elsenosy YA, Abd OM. Biochemical effect of Costus speciosus on erlich ascites carcinoma (EAC) in female albino mice. Benha Vet Med J 2014;26:200-21.

65. Selim S, Al Jaouni S. Anticancer and apoptotic effects on cell proliferation of diosgenin isolated from Costus speciosus (Koen.) Sm. BMC Complement Altern Med 2015;15:1-7.

66. Widastuti EL, Susanto GN, Rudini M, Kanedi M. Ameliorative properties of crude diosgenin from Costus speciosus and taurine on testicular disorders in alloxan-induced diabetic mice. Biomed Pharmacol J 2017;10:9-17.

67. Hermawan A, Meiyanto E. Hesperidin meningkatkan doxorubicin pada Sel MCF-7 efek sitotoksik. Maj Farm Indones 2010;21:8-17.

68. Roy A, Manikkam R. Cytotoxic impact of costunolide isolated from costus speciosus on breast cancer via differential regulation of cell cycle-an in-vitro and in-silico approach. Phytother Res 2015;29:1532-9.

69. Rajalakshmi M, Anita R. in vitro and in silico evaluation of antioxidant activity of a sesquiterpene lactone, costunolide, isolated from Costus speciosus rhizome on Mcf-7 and Mda-Mb-231 human breast cancer cell lines. World J Pharm Pharm Sci 2014;3:1334-47.

70. Harahap U, Nasution MP, Ilyas S. The activity of cytotoxic activity, proliferation inhibition and apoptosis induction of Rhaphidohora pinnata (LF) schott chloroform fraction to MCF-7 cell line. Adv Biol Chem 2013;3:397-402.

71. Rani PU, Pratyusha S. Defensive role of Gossypium hirsutum L. anti-oxidative enzymes and phenolic acids in response to Spodoptera litura F. feeding. J Asia Pac Entomol 2013;16:131-6.

72. El-Sharaky AS, Newairy AA, Elguindy NM, Elwafa AA. Spermatotoxicity, biochemical changes and histological alteration induced by gossypol in testicular and hepatic tissues of male rats. Food Chem Toxicol 2010;48:3354-61.

73. Cui GH, Xu ZL, Yang ZJ, Xu YY, Xue SP. A combined regimen of gossypol plus methyltestosterone and ethinylestradiol as a contraceptive induces germ cell apoptosis and expression of its related genes in rats. Contraception 2004;70:335-42.

74. Macoska JA, Adsule S, Tantivejkul K, Wang S, Pienta KJ, Lee CT. Gossypol promotes the apoptosis of bladder cancer cells in vitro. Pharmacol Res 2008;58:323-31.

75. Qu J, Wang Y. Gossypol potentiates carboplatin effects against ovarian cancer. Biomed Res 2017;28:3355-61.

76. Gadelha IC, de Macedo MF, Oloris SC, Melo MM, Soto-Blanco B. Gossypol promotes degeneration of ovarian follicles in rats. ScientificWorldJournal 2014;2014:986184.

77. Basini G, Bussolati S, Baioni L, Grasselli F. Gossypol, a polyphenolic aldehyde from cotton plant, interferes with swine granulosa cell function. Domest Anim Endocrinol 2009;37:30-6.

78. Atmaca H, Gorumlu G, Karaca B, Degirmenci M, Tunali D, Cirak Y, et al. Combined gossypol and zoledronic acid treatment results in synergistic induction of cell death and regulates angiogenic molecules in ovarian cancer cells. Eur Cytokine Netw 2009;20:121-30.

79. Maganha EG, Halmenschlager RC, Rosa RM, Henriques JA, Ramos AL, Saffi J. Pharmacological evidences for the extracts and secondary metabolites from plants of the genus Hibiscus. Food Chem 2010;118:1-10.

80. Vasudeva N, Sharma SK. Biologically active compounds from the genus Hibiscus. Pharm Biol 2008;46:145-53.

81. Lin HH, Chan KC, Sheu JY, Hsuan SW, Wang CJ, Chen JH. Hibiscus sabdariffa leaf induces apoptosis of human prostate cancer cells in vitro and in vivo. Food Chem 2012;132:880-91.

82. Lo CW, Huang HP, Chan KC, Wu CH, Wang CJ. Hibiscus sabdariffa extract induced apoptosis of proliferating smooth muscle cell. J Food Biochem 2010;34:549-63.

83. Wu $\mathrm{CH}$, Huang $\mathrm{CC}$, Hung $\mathrm{CH}$, Yao FY, Wang $\mathrm{CJ}$, Chang YC. Delphinidin-rich extracts of Hibiscus sabdariffa L. trigger mitochondria-derived autophagy and necrosis through reactive oxygen species in human breast cancer cells. J Funct Foods 2016;25:279-90.

84. Tripathi A, Tandon M, Chandekar A, Soni N. In vitro antioxidant and anthelmintic activity on Luffa cylindrica leaf extracts. J Herbs Spices Med Plants 2016;22:348-55.

85. Liu L, Wang R, He W, He F, Huang G. Cloning and soluble expression of mature alpha-luffin from Luffa cylindrica and its antitumor activities in vitro. Acta Biochim Biophys Sin (Shanghai) 2010;42:585-92.

86. Igboro SB. Determination of the filter potential of luffa sponge ( $\mathrm{Luffa}$ aegyptica) in water quality analysis department of water resources and environmental engineering department of civil engineering. Am Int J Contemporary Res 2013;3:117-23

87. Popovich DG, Li L, Zhang W. Bitter melon (Momordica charantia) triterpenoid extract reduces preadipocyte viability, lipid accumulation and adiponectin expression in 3T3-L1 cells. Food Chem Toxicol 2010;48:1619-26.

88. Cr S, Vishwanath P, Mn S, Prashant A, Rangaswamy C. In vitro anticancer activity of ethanolic extract of Momordica charantia on cervical and breast cancer cell lines. Int J Health Allied Sci. 2015;4:210-7.

89. Tumkiratiwong P, Ploypattarapinyo R, Pongchairerk U, Thong-Asa W. Reproductive toxicity of Momordica charantia ethanol seed extracts in male rats. Iran J Reprod Med 2014;12:695-704.

90. Joseph B, Jini D. Antidiabetic effects of Momordica charantia (bitter melon) and its medicinal potency. Asian Pac J Trop Dis 2013;3:93-102.

91. Ilyas S, Lestari SW, Moeloek N, Asmarinah, Siregar NC. Induction of rat germ cell apoptosis by testosterone undecanoate and depot medroxyprogesterone acetate and correlation of apoptotic cells with sperm concentration. Acta Med Indones 2013;45:32-7.

92. Ilyas S. Effect of methanolic Momordica charantia seed extract and depot medroxyprogesterone acetate (DMPA) to quantity and quality of rat sperm. Int J PharmTech Res 2014;6:1817-23.

93. Li CJ, Tsang SF, Tsai CH, Tsai HY, Chyuan JH, Hsu HY, et al. Momordica charantia extract induces apoptosis in human cancer cells through caspase- and mitochondria-dependent pathways. Evid Based Complement Alternat Med 2012;2012:261971.

94. Birla D, Sonali KA, Shaikh A, Khan A, Ghosi A, Pardeshi P, et al. Evaluation of antimutagenic activity of methanolic extract of leaves of Momordica charantia Linn. Int J Health Med 2017;5:81-3.

95. Ilyas S, Hutahaean S, Nursal. Apoptosis overview of cerebellum Purkinje cell in mice (Mus musculus L.) after exposure to methanol extract of the seeds of bitter melon (Momordica charantia) and DMPA. Int J PharmTech Res 2016;9:1-8.

96. Ilyas S, Hutahaean S, Biologi D, Matematika F, Alam P. Pengaruh ekstrak methanol biji pare (Momordica charantia) dan DMPA terhadap jumlah sel purkinje cerebellum mencit (Mus musculus L.). Prosiding Semin Natl Basic Sci Sci Compr Educ 2016;248-50.

97. Jana K, Jana N, De DK, Guha SK. Ethanol induces mouse spermatogenic cell apoptosis in vivo through over-expression of fas/Fas-L, p53, and caspase-3 along with cytochrome $\mathrm{c}$ translocation and glutathione depletion. Mol Reprod Dev 2010;77:820-33.

98. Elkady AI, El-Hamidy SM. Induction of growth arrest and apoptosis in human lung cancer cells by crude saponin extract isolated from Nigella sativa. Life Sci J 2013;10:2529-36. 
99. Perveen H, Dash M, Khatun S, Maity M, Islam SS, Chattopadhyay S, et al. Electrozymographic evaluation of the attenuation of arsenic induced degradation of hepatic SOD, catalase in an in vitro assay system by pectic polysaccharides of Momordica charantia in combination with curcumin. Biochem Biophys Rep 2017;11:64-71.

100. Yama OE, Bassey RB, Amah CI, Oyebadejo SA, Oremosu AA. Antagonistic salubrious effects of Tahitian Noni in Momordica charantia-induced cytoarchitectural alterations in rat testes: Parallel light microscopic findings. Int J Nutr Metabol 2012;4:40-4

101. Bhawsar J, Jain PK, Jain P. Experimental and computational studies of Nicotiana tabacum leaves extract as green corrosion inhibitor for mild steel in acidic medium. Alexandria Eng J 2015;54:769-75.

102. Paccola CC, Miraglia SM. Prenatal and lactation nicotine exposure affects sertoli cell and gonadotropin levels in rats. Reproduction 2016;151:117-33.

103. Menon R, Fortunato SJ, Yu J, Milne GL, Sanchez S, Drobek CO, et al. Cigarette smoke induces oxidative stress and apoptosis in normal term fetal membranes. Placenta 2011;32:317-22.

104. Lagunov A, Anzar M, Sadeu JC, Khan MI, Bruin JE, WoynillowiczAK, et al. Effect of in utero and lactational nicotine exposure on the male reproductive tract in peripubertal and adult rats. Reprod Toxicol 2011;31:418-23

105. Mamsen LS, Lutterodt MC, Andersen EW, Skouby SO, Sørensen KP, Andersen CY, et al. Cigarette smoking during early pregnancy reduces the number of embryonic germ and somatic cells. Hum Reprod 2010;25:2755-61.

106. Maccani MA, Avissar-Whiting M, Banister CE, McGonnigal B, Padbury JF, Marsit CJ, et al. Maternal cigarette smoking during pregnancy is associated with downregulation of miR-16, miR-21, and miR-146a in the placenta. Epigenetics 2010;5:583-9.

107. Anderson RA, McIlwain L, Coutts S, Kinnell HL, Fowler PA, Childs AJ, et al. Activation of the aryl hydrocarbon receptor by a component of cigarette smoke reduces germ cell proliferation in the human fetal ovary. Mol Hum Reprod 2014;20:42-8.

108. Mosadegh M, Hasanzadeh S, Razi M. Nicotine-induced damages in testicular tissue of rats; Evidences for bcl-2, p53 and caspase-3 expression. Iran J Basic Med Sci 20:199-208.

109. Okoye J, Ngokere A. Estrogenic and hypocholesterolemic effects of aqueous extract of Nicotiana tabacum (Tobacco) on the micro-anatomical architecture of the testis in male albino. $\mathrm{Br} \mathrm{J}$ 2014;4:2194-220.

110. Ijomone OM, Olaibi OK, Nwoha PU. Effects of chronic nicotine administration on body weight, food intake and nitric oxide concentration in female and male rats. Pathophysiology 2014;21:185-90.

111. Fezai M, Senovilla L, Jemaà M, Ben-Attia M, Ben-Attia M. Analgesic, anti-inflammatory and anticancer activities of extra virgin olive oil. J Lipids 2013;2013:1-7.

112. Herwanto RY, Bashiruddin J, Ilyas S, Lubis MN. Correlation of noise intensity to heat shock response with ultrastructure region of Rattus norvegicus' scochlea. Int J PharmTech Res 2015;7:80-4.

113. Herwanto RY, Ilyas S, Indharty RS. HSP70 gene expression in serum and tissue of rat cochlear (Rattus norvegicus) due to noise exposure and heat. Int J PharmaTech Res 2016;9:58-63

114. Yusuf F, Ilyas S, Damanik HA, Fatchiyah F. Microbiota composition, HSP70 and caspase-3 expression as marker for colorectal cancer patients in aceh, Indonesia. Acta Med Indones 2016;48:289-99.

115. Santiago-Font JA, Amaral LM, Faulkner J, Ibrahim T, Vaka VR, Cunningham MW, et al. Serelaxin improves the pathophysiology of placental ischemia in the reduced uterine perfusion pressure rat model of preeclampsia. Am J Physiol Regul Integr Comp Physiol 2016;311:R1158-63.

116. Menendez JA, Vazquez-Martin A, Garcia-Villalba R, CarrascoPancorbo A, Oliveras-Ferraros C, Fernandez-Gutierrez A, et al. TabAnti-HER2 (erbB-2) oncogene effects of phenolic compounds directly isolated from commercial extra-virgin olive oil (EVOO). BMC Cancer 2008;8:377.

117. Notarnicola M, Pisanti S, Tutino V, Bocale D, Rotelli MT, Gentile A, et al. Effects of olive oil polyphenols on fatty acid synthase gene expression and activity in human colorectal cancer cells. Genes Nutr 2011;6:63-9

118. Gill CI, Boyd A, McDermott E, McCann M, Servili M, Selvaggini R, et al. Potential anti-cancer effects of virgin olive oil phenols on colorectal carcinogenesis models in vitro. Int J Cancer 2005;117:1-7.

119. Lozano-Sánchez J, Segura-Carretero A, Menendez JA, OliverasFerraros C, Cerretani L, Fernández-Gutiérrez A, et al. Prediction of extra virgin olive oil varieties through their phenolic profile. Potential cytotoxic activity against human breast cancer cells. J Agric Food Chem 2010;58:9942-55

120. Elamin MH, Daghestani MH, Omer SA, Elobeid MA, Virk P, Al-Olayan EM, et al. Olive oil oleuropein has anti-breast cancer properties with higher efficiency on ER-negative cells. Food Chem Toxicol 2013;53:310-6.

121. Solanas M, Grau L, Moral R, Vela E, Escrich R, Escrich E. Dietary olive oil and corn oil differentially affect experimental breast cancer through distinct modulation of the p21Ras signaling and the proliferation-apoptosis balance. Carcinogenesis 2009;31:871-9.

122. Amel N, Wafa T, Samia D, Yousra B, Issam C, Cheraif I, et al. Extra virgin olive oil modulates brain docosahexaenoic acid level and oxidative damage caused by 2,4-dichlorophenoxyacetic acid in rats. J Food Sci Technol 2016;53:1454-64.

123. Sakr SA, Nooh HZ. Effect of Ocimum basilicum extract on cadmiuminduced testicular histomorphometric and immunohistochemical alterations in albino rats. Anat Cell Biol 2013;46:122-30.

124. Sharma J, Khurana N, Sharma N, Garg R. Phytochemical evaluation and antioxidant screening studies of Ocimum tenuiflorum Linn seeds. Asian J Pharm Clin Res 2017;10:76.

125. Ainehchi N, Khaki A, Merat E. Ocimum basilicum extract ameliorate lead-induced testicular apoptosis in rats. Afr J Tradit Complement Altern Med 1998;80:98-103

126. Manaharan T, Thirugnanasampandan R, Jayakumar R, Kanthimati MS, Ramya G, Ramnath MG. Purifed esential Oil from Ocimum sanctum Linn. Triggers the apoptotic mechanism in human breast cancer celss. Pulmed 2016;46:32.

127. Srinivasulu K, Sivakumar E, Changamma C. The Effective role of ursolic acid and Ocimum sanctum (Linn.) leaf extract on some marker carbohydrate metabolites in male albino rats. Int J Pharm Sci Res 2017:8:4624-36.

128. Kusindarta DL, Wihadmadyatami H, Haryanto A. Ocimum sanctum linn. Stimulate the expression of choline acetyltransferase on the human cerebral microvascular endothelial cells. Vet World 2016;9:1348-54

129. Mansouri E, Khaki A. The effect of Citrus aurantium on uterus apoptosis and serum antioxidants in rats exposed to electromagnetic fields. Crescent J Med Biol Sci 2014;1:143-6.

130. Ghasemzadeh A, Jaafar HZ, Rahmat A. Antioxidant activities, total phenolics and flavonoids content in two varieties of malaysia young ginger (Zingiber officinale roscoe). Molecules 2010;15:4324-33.

131. Sakr SA, Badawy GM. Effect of ginger (Zingiber officinale R.) on metiram-inhibited spermatogenesis and induced apoptosis in albino mice. J Appl Pharm Sci 2011;1:131-6.

132. Morakinyo AO, Achema PU, Adegoke OA. Effect of Zingiber Officinale (Ginger) on sodium arsenite-induced reproductive toxicity in male rats. Afr J Biomed Res 2010;13:39-45.

133. Rasyidah TI, Suhana S, Kaswandi MA, Noah RM. Evaluation of antioxidant activity of Zingiber officinale (ginger) on formalininduced testicular toxicity in rats. J Med Bioeng 2014;3:149-53.

134. Akbari A, Nasiri K, Heydari M, Mosavat SH, Iraji A. The protective effect of hydroalcoholic extract of Zingiber officinale Roscoe (Ginger) on ethanol-induced reproductive toxicity in male rats. J Evid Based Complement Altern Med 2017;22:609-17.

135. Sakr SA. Ameliorative effect of ginger (Zingiber officinale) on mancozeb fungicide induced liver injury in albino rats. Aust J Basic Appl Sci 2007;1:650-6

136. AL-Neamah GA. Protective effect of ginger (Zingiber Officinal) hydro alcoholic extract on cadmium chloride induced reproductive toxicity in rats female. Euphrates J Agric Sci 2016;8:8-16.

137. Liu Y, Whelan RJ, Pattnaik BR, Ludwig K, Subudhi E, Rowland H, et al. Terpenoids from Zingiber officinale (Ginger) induce apoptosis in endometrial cancer cells through the activation of p53. PLoS One 2012; $7:$ e53178.

138. Ghasemzadeh A, Jaafar HZ. Antioxidant potential and anticancer activity of young ginger (Zingiber officinale Roscoe) grown under different CO concentration. J Med Plant Res 2011:5:3247-55.

139. Kapoor V, Aggarwal S, Das SN 6-gingerol mediates its anti tumor activities in human oral and cervical cancer cell lines through apoptosis and cell cycle arrest. Phytother Res 2016;30:588-95.

140. Ekowati H, Achmad A, Prasasti E, Wasito H, Sri K, Hidayati Z, et al. Zingiber officinale, Piper retrofractum and combination induced apoptosis and p53 expression in myeloma and WiDr cell lines. HAYATI J Biosci 2012;19:137-40.

141. Muhammad Nadzri N, Abdul AB, Sukari MA, Abdelwahab SI, Eid EE, Mohan S, et al. Inclusion complex of zerumbone with hydroxypropyl- $\beta$-cyclodextrin induces apoptosis in liver 
hepatocellular hepG2 cells via caspase 8/BID cleavage switch and modulating bcl2/Bax ratio. Evid Based Complement Alternat Med 2013;2013:810632.

142. Saber SA, Hawazen LA, Amina EE. Ginger (Zingiber officinale) extract ameliorates metalaxyl fungicide induced nephrotoxicity in albino mice. Afr J Pharm Pharmacol 2011;5:104-12.

143. Oliveira PF, Sousa M, Barros A, Moura T, Rebelo DC. Intracellular $\mathrm{pH}$ regulation in human sertoli cells: Role of membranes transporters. Reproduction 2009;137;2:353-359, 7-331.

144. Sharpe RM, McKinnell C, Kivlin C, Fisher JS. Proliferation and functional maturation of sertoli cells, and their relevance to disorders of testis function in adulthood. Reproduction 2003;125:769-84

145. Laurentino S, Gonçalves J, Cavaco JE, Oliveira PF, Alves MG, de Sousa M, et al. Apoptosis-inhibitor aven is downregulated in defective spermatogenesis and a novel estrogen target gene in mammalian testis. Fertil Steril 2011;96:745-50.

146. Laurentino SS, Correia S, Cavaco JE, Oliveira PF, de Sousa M, Barros A, et al. Regucalcin, a calcium-binding protein with a role in male reproduction? Mol Hum Reprod 2012;18:161-70.

147. Weikert S, Schrader M, Müller M, Schulze W, Krause H, Miller K, et al. Expression levels of the inhibitor of apoptosis survivin in testes of patients with normal spermatogenesis and spermatogenic failure. Fertil Steril 2005;83 Suppl 1:1100-5.

148. Shaha C, Tripathi R, Mishra DP. Male germ cell apoptosis: Regulation and biology. Philos Trans R Soc Lond B Biol Sci 2010;365:1501-15.

149. Aitken RJ, Findlay JK, Hutt KJ, Kerr JB. Apoptosis in the germ line. Reproduction 2011;141:139-50.

150. Bozec A, Amara S, Guarmit B, Selva J, Albert M, Rollet J, et al. Status of the executioner step of apoptosis in human with normal spermatogenesis and azoospermia. Fertil Steril 2008;90:1723-31.

151. Kim SK, Yoon YD, Park YS, Seo JT, Kim JH. Involvement of the fas-fas ligand system and active caspase- 3 in abnormal apoptosis in human testes with maturation arrest and sertoli cell-only syndrome. Fertil Steril 2007;87:547-53.

152. Almeida C, Correia S, Rocha E, Alves A, Ferraz L, Silva J, et al. Caspase signalling pathways in human spermatogenesis. J Assist Reprod Genet 2013;30:487-49.

153. Tilly JL. Commuting the death sentence: How oocytesstrive to survive. Nat Rev Mol Cell Biol 2001;2:838-84.

154. Hutt KJ. The role of BH3-only proteins in apoptosis withinthe ovary. Reproduction 2015;49:R81-9.

155. Matsuda F, Inoue N, Manabe N, Ohkura S. Follicular growth and atresia in mammalian ovaries: Regulation by survival and death of granulosa cells. J Reprod Dev 2012;58:44-50.

156. Morita Y, Tilly JL. Oocyte apoptosis: Like sand through an hourglass. Dev Biol 1999;213:1-17.

157. Liew SH, Vaithiyanathan K, Cook M, Bouillet P, Scott CL, Kerr JB, et al. Loss of the proapoptotic BH3-only protein BCL-2 modifying factor prolongs the fertile life span in female mice. Biol Reprod 2014;90:77.

158. Pandey AN, Tripathi A, Premkumar KV, Shrivastav TG, Chaube SK. Reactive oxygen and nitrogen species during meiotic resumption from diplotene arrest in mammalian oocytes. J Cell Biochem 2010;111:521-8

159. Tripathi A, Kumar KV, Chaube SK. Meiotic cell cycle arrest in mammalian oocytes. J Cell Physiol 2010;223:592-600.

160. Irianti E, Rosidah S, Hutahaean S. Hsp70 expression profile in preeclampsia model of pregnant rat (Rattus norvegicus) after giving the EVOO. Mater Sci Eng 2017;180;12161.

161. Qamar KA, Ahsana D, Bina SS, Nurul K, Huma A, Shakil A, et al. Anticancer activity of Ocimum basilicum and the effect of ursolic acid on the cytoskeleton of MCF-7 human breast cancer cells. Lett Drug Design Discovery 2010;27:726-36.

162. Khaki A, Fatemeh F, Mohammad N, Amir AK. Effect of Ocimum basilicum on apoptosis in testis of rats after exposure to electromagnetic field. Afr J Pharm Pharmacol 2011;5:1534-7.

163. Elkady AI, Abuzinadah OA, Baeshen NA, Rahmy TR. Differential control of growth, apoptotic activity, and gene expression in human breast cancer cells by extracts derived from medicinal herbs Zingiber officinale. J Biomed Biotechnol 2012;2012:614356.

164. Syafruddin I. Combination of testosterone undecanoate (TU) and water extract of Medan blustru (Luffa aegyptica Milt) as alternatif in male contraceptive. J Indones Med Assoc 2011;61:10.

165. Oyetayo FL, Oyetayo VO, Ajewole V. Phytochemical profile and antibacterial properties of the seed and leaf of the luffam plant (Luffa cylindrica). J Pharmacol Toxicol 2007;2:586-9.

166. Shaikh S, Vandana J. Development and validation of a RP-HPLC method for the simultaneous determination of curcumin, piperine and camphor in an ayurvedic formulation. Int $\mathrm{J}$ Pharm Pharm Sci 2018;10:115-21.

167. Ashraf KK, Altaf A, Syed AS, Mohd M. Genetic diversity in accessions of Indian turmeric (Curcuma longa L.) using RAPD markers. Int J Pharm Pharm Sci 2017;9:288-91. 